\title{
Working Conditions for Female and Immigrant Cleaners in Stockholm County - An Intersectional Approach
}

I Saeid Abbasian

Ph.D, Mid Sweden University, Östersund, Sweden ${ }^{1}$

I Carina Hellgren

Docent, International Programme Office, Stockholm, Sweden

\begin{abstract}
This paper deals with the working and employment conditions of cleaners with an overview of Sweden but with main emphasis on the Stockholm region. The article is based on a review of previous research, statistics from Sweden, and interviews with cleaners and owners of cleaning firms. Results indicate that working conditions among Swedish cleaners are generally unfavorable with regard to employment contracts and the low status of the profession. Conditions seem to be worst in the Stockholm region, with its turbulent market. The cleaning industry in the Stockholm region consists of too many firms and there is an adverse business climate within this regional industry. We argue that there is a connection to the model of intersectionality, which implies that there is an interlinking of identity constructions and socially organizing principles in terms of class, gender, ethnicity/ "race," and citizenship. Cleaning or charwork constitutes one of the lowest working-class positions in society. Cleaners are at the bottom of the hierarchy, below the owners and other white-collar workers in the industry. The majority of cleaners in the region are women and/or of immigrant origin, not least men and women from non-European countries; many have low educational levels, low proficiency in the Swedish language, and deficient knowledge of laws and regulations. All these factors add up to powerlessness, something that aggravates the situation for the cleaners in the county.
\end{abstract}

\section{KEY WORDS}

Cleaners / Employment contracts / Immigrants / Intersectionality / Stockholm County / Unions I Working conditions

\section{Introduction}

leaning or charwork is a female-dominated profession that has one of the lowest statuses in Swedish working life (Ulfsdotter Eriksson 2006). After professional cleaner and author Maja Ekelöf (1970) described her everyday working life in her bestselling novel Rapport frä en skurbink (Report from a Moping Bucket), Swedes have become more familiar with the working conditions for this low-paid group of the working class. In Ekelöf's novel, we follow her difficult job and night work, her poor working conditions, and her concerns about how to support her five

\footnotetext{
${ }^{1}$ Saeid Abbasian, Ph.D, Institution for Social Science, Mid Sweden University, Östersund- Sweden. E-mail: saeid.abbasian@miun.se
} 
children on an insufficient salary. Despite technical improvements and better rules compared with Ekelöf's time, many problems still remain in cleaning jobs and the cleaning industry.

Focus in this study lies on the cleaning industry in Sweden, in particular on the County of Stockholm. The paper emphasizes working and employment conditions in general, with specific emphasis on part-time/un/employment as one of the main indicators of insufficient working and employment conditions in the industry.

After the Second World War, Sweden had high employment rates for both men and women, mostly due to the successful development of the manufacturing industry. Over the past decades, though, the manufacturing industry has lost its dominance in the country's trade and industry, while the labor market has become more differentiated, with a rapidly growing service sector. A substantial part of the Swedish labor force is now working part-time in various labor market segments, including the cleaning industry. The labor force does not have much of a choice; only part-time jobs are available for many of them (Nyberg 2003). Part-time/un/employment, i.e., involuntary part-time hours, affects non-European immigrant women to a larger extent than it does Swedish or Nordic women (Nelander \& Bendetcedotter 2001).

Traditionally, a normal working week in Sweden has been equivalent to 40 hours. Working hours of 20 to 34 hours per week are defined as part-time, while working hours of less than 20 hours per week are considered short part-time. In many other countries, part-time work is defined as 19 hours or less per week and full-time or long-time work as 20 hours and more (Stark \& Regnér 2001). The prevalence of part-time contracts and other atypical forms of employment, such as being employed by the hour, has been growing since the 1990s (Jonsson \& Wallette 2001). There are two types of part-time unemployed in Sweden: persons who are unemployed full-time but wish to work part-time and consequently therefore only qualify for part-time unemployment benefits, and persons who already have a part-time job but are looking for complementary work (Pettersson 2005). The second category is defined as involuntary part-time. This category also includes persons who work on temporary contracts, such as being employed by the hour rather than on a full-time and full-year contract.

This paper is based on a previous research and development project (Abbasian 2006) that mainly concerned bad working conditions and environments within Stockholm County's cleaning industry. The main focus was on involuntary part-time employment as one of the principal indicators of bad working conditions in that industry. The research was done in collaboration with the two trade unions that organize cleaners (FastighetsEttan and Byggettan) and with two of their project leaders. The purpose was to improve conditions for union members in the cleaning sector, in particular women and immigrant members, and among other things to facilitate more full-time working schedules.

Based on relevant literature and our empirical studies, we wish to provide a deeper understanding of how structural changes in the public sector have given rise to a rapidly growing cleaning sector over the past decades and how ordinary cleaners (racialized men and women and native-born women), as a consequence of these changes, are forced to bear the industry's problems of bad employment and working conditions, among others with part-time/un/employment. 


\section{Aims and questions}

Our aim is to study working and employment conditions for cleaners in Stockholm County, with a specific focus on involuntary part-time employment among female and immigrant cleaners. We seek answers to the following questions:

- What is known about the cleaning industry in Stockholm County with regard to working and employment conditions for cleaners, especially women and immigrants?

- Can part-time employment be explained, not least involuntary part-time?

- Will the theoretical model of intersectionality help to explain the situation?

Through intersectionality, a concept used in the social sciences and gender research, we try to describe and analyze the vulnerable situation of cleaners in the county of Stockholm. The concept serves both as a theoretical model and as an analytical tool to study how different types of discriminatory orders of power and powerlessness interact, resulting in inequality in the labor market (Dahl 2005). The most commonly used interacting dimensions, often expressed as identity categories or identity constructions, are the socially and culturally constructed categories of gender, class, ethnicity, and race. Other categories are citizenship, sexual orientation, and disability, but sometimes also age and health status. Within each dimension, there are also sub-dimensions (see, e.g., Lundahl 2006). Women are, for example, considered as subordinate to men. But women also represent different classes, different ethnic and racialized groups and citizenships, all of which are socially organizing dimensions that affect their situation in different ways. These dimensions and sub-dimensions intersect in the interplay of power and powerlessness.

Intersectionality was initially a reaction from black and Third World feminists seeking to question the dominant gender-based research in Western countries, which focused on white women's subordination, while excluding women and men from other ethnicities/races (see, e.g., hooks 1981, 1984, 1988; Mohanty 1984, 1991). As Knudsen (2006) puts it, researchers try to catch the workings of the relationship between sociocultural categories and identities by using this analytical tool.

Starting in the mid-1980s, researchers of immigrant origin in Sweden (e.g., Ålund 1985; Knocke 1986) began to study and analyze inequalities, powerlessness, and subordination in working life by highlighting the interaction of gender, class, and ethnicity. The concept of intersectionality was later introduced by researchers belonging to the LatinAmerican diaspora to distinguish between exploited and stigmatized categories and for a critical assessment of ethnocentric Swedish feminist studies (de los Reyes and Mulinari 2005; de los Reyes et al. 2002; Mulinari 2007). The theory shows how "the others," in particular women from minorities, are understood, marginalized, and excluded or included by the majority (ibid). We will return to the concept in the form of a model or conceptional tool where we try to visualize the core components affecting employment and other working conditions for cleaners, with emphasis on the region of Stockholm.

\section{An important structural change}

The Swedish public sector has changed radically over the last few decades. Previously a country with a welfare-state regime and a large public sector, Sweden has been 
transformed into a more market-oriented country. This so-called New Public Management (NPM) has meant reducing public sector expenses, privatization or outsourcing of public sector responsibilities, and accepting market rules (Sundin \& Rapp 2006). The public and private sectors have become competitors in performing public service contracts (Gonäs et al. 1997). Cleaners, especially those formerly employed by the public sector, have been directly and negatively affected by this new type of management.

From having been a major employer, the public sector went through a structural change in the 1990s, being transformed into a client of the cleaning industry. The structural transformation resulted in a client-server model. Before the reform, cleaners were employed in the public sector. The reform involved cleaning work being outsourced to private entrepreneurs. Private cleaning companies were free to compete in the public sector as well as on the municipal market. Female cleaners employed in the public sector were encouraged to start cleaning firms, rather than seeking to remain employed. One typical example comes from the city of Linköping, where many of those who were employed by the municipality found themselves in a very disadvantageous situation. The municipal cleaning department was forced to compete with private cleaning firms under unfavorable conditions and give low price offers. The consequence was that many female cleaners were forced to clean larger areas or had to move between a number of smaller cleaning areas, in shorter and more inconvenient working hours. They were forced to share their working hours with others and content themselves with part-time working. In addition, a number of cleaners had to live under the constant threat of being given notice (Sundin \& Rapp 2006). A study by Marklund and Ekenvall (1998) has shown how low-educated immigrant female cleaners employed by Karolinska University Hospital were negatively affected both psychologically and physically by being given notice due to the new circumstances and rules.

In the procurement procedure, cleaning firms give the client a price for the job, normally covering 2 years. The firm offering the lowest price has the greatest chance of getting the contract, even though this could mean poor quality service as well as bad wages and working conditions for the cleaners. With some months' notice, toward the end of the contract term, it is time for a new procurement procedure. The cleaning firm may have provided good quality service but, even though the firm has offered a low price, there is always a risk of losing the new contract when a rival company offers an even lower price. Price war makes it possible for less professional firms to gain advantage in the market and the quality of the industry risks deterioration. Service contractors also often choose other firms, and the cleaners are the ones to suffer most (Fastighet's folket 2/2005).

\section{The cleaning industry: an overview of sweden}

In Sweden, there is a great variety of cleaning jobs and many different specializations, from bus cleaner to aircraft cleaner, office cleaner, hospital cleaners, and so on (SCB 2005c). Cleaners represent one of the 20 most common occupational groups. In 2002, as many as 66,000 gainfully employed persons were cleaners, $80 \%$ of whom were women (SCB $2005 \mathrm{a}, \mathrm{b})$. Of all cleaners in the country, $31 \%$ were persons of foreign origin (SCB 2003).

In cleaning firms, there is a hierarchy that manifests itself in different job titles and wages. The owner of the firm (managing director/MD) and the deputy MD are at the 
top and ordinary cleaners are at the bottom, which is hardly surprising. Between them we find positions which, more or less, have the characteristics of white-collar jobs. The Swedish Municipal Workers' Union distinguishes between four such different positions: cleaning inspector, principal cleaner, chief cleaner, and cleaning instructor (statistics from the Swedish Municipal Workers' Union, March and April 2005).

There are approximately 1,500 cleaning firms in Sweden with employees and 3,000 one-man firms. The industry has a few very large firms, a shrinking number of middlesized firms, and many small and one-man firms. The industry's economic turnover is approximately SEK 17 billion per year (equivalent to \$2.3 billion in 2005). The market is very turbulent, and mergers and renaming of firms are common. Part-time work is widespread and less professional employers and workers originating from the irregular or informal sector are prevalent in the industry (Sundin 2005).

Cleaning is characterized as a low-paid, low-qualified, and typically female lowstatus working-class job. At a large Swedish cleaning firm, Aurell (2001) found widespread gender segregation between female and male cleaners. Men earned higher wages than women and worked mainly full-time, while women worked mainly part-time and often did unpaid overtime. Men performed so-called special cleaning, such as windowcleaning, which was the least profitable area for the firm, while women took care of ordinary cleaning, which generated the best profit. Women were not allowed to work as special cleaners since the job was considered too heavy for them, according to the management of the company (ibid).

Cleaning in general and window-cleaning in particular are two of the most dangerous and hazardous jobs in Sweden when it comes to injuries and various types of allergic problems (Prevent 2003, 2012). Cleaning is physically and mentally a very arduous job; this can lead to ill-health and increased sick leave (Akhavan \& Bildt 2004). All this contributes to a negative attitude toward the job, something that has been experienced by many cleaners, whether native born or immigrants. While writing her masters thesis, the sociologist Josefina Palmgren experienced and observed this personally when working as a cleaner, using observation as a methodological tool. Her results pointed to the occurrence of indifference and other types of unsuitable behavior toward the cleaners from employees in the workplaces where the cleaning was performed (Palmgren 1995).

Irregular employment (cash-in-hand jobs) and low tax morale in many firms are great problems in the Swedish cleaning industry. Typically, irregular employment involves working full-time in a firm; however, in agreement with the firm's owner, only $50 \%$ of the working time is reported to the tax authorities. Part-time unemployment benefits and a $50 \%$ irregular payment from the employer are received to cover the remaining time. This also implies that the employer avoids paying the $50 \%$ social security contributions connected with the job (FastighetsEttan 2005). Another problem is the employment of immigrants without residence permits, who are being paid irregular wages far below the standard (Fredholm 2003). One more problem in the industry is low non-contractual wages. The setting of wage rates varies from region to region and from union to union, as well as among cleaners doing different types of jobs.

Different unions apply different wage levels and conditions for their members, such as, for example, compensation for inconvenient working hours. Minimum hourly entrance wages set by the unions were between 85 and 95 SEK in 2005. Average full-time monthly wages for a cleaner in the country, however, very likely arrived, before deduction for taxes, at between 16,000 and 17,000 SEK $(€ 1,700-1,800)$ for the members of 
all these unions (Telephone interviews with union representatives of FastighetsEttan, Byggettan and Kommunal June 15, 2005 and E- mail interview with the representative of union FastighetsEttan June 20, 2005). ${ }^{1}$

\section{The geographical context}

The county of Stockholm is the core of our research interest. This is the most populated region of Sweden, with major spatial importance for both native inhabitants and immigrants, as well as for the rest of the country.

With ministries, authorities, banks, universities, new industries, a number of international firms, hotels, and conference venues, the Stockholm region is the largest labor market in Sweden. Many small and middle-sized municipalities are tightly integrated with the city of Stockholm, and it is also closely linked to other important regional centers in neighboring counties. The short distances between them make it possible for many people to live in one municipality and work in another.

The expansive economy of the Stockholm region offers multifaceted opportunities to run a business for both native Swedes and immigrants. In the regional market, there is potential for both highly qualified jobs and low-paid service-oriented businesses, like businesses run by immigrants. The majority of low-paid but well-educated immigrant entrepreneurs offer various types of services to the majority of Stockholm's inhabitants, ranging from professional elite groups, to business owners, to experts and employees in international companies (Ålund 2002). Immigrants who are unable to start their own business can find a job in this type of service-oriented company relatively easily. One example of such a service is the cleaning industry. As much as $54 \%$ of all joint-stock cleaning firms in Sweden, as well as $70 \%$ of all employees and $66 \%$ of the total economic turnover in the country, come from Stockholm County (D \& B 2004).

Moving our attention to the cleaning industry in the county of Stockholm, it is clear that far too many firms have been established (1,200 firms in 2004, according to applications from Byggettan and FastighetsEttan). Consequently, there is a tough business climate within the regional industry with great competition to get contracts. The predominant majority of the staff in the firms are ordinary cleaners, both native-born women and immigrants, mostly from non-European countries. Their immigrant status makes their situation more vulnerable. Many of them lack a network of contacts and may have insufficient language skills and are therefore more badly affected by the tough business climate than native Swedes are. Among 1,100 registered full-time and part-time unemployed cleaners in 2004, a predominant majority were immigrants. They often receive little or no training by their employers (Application from FastighetsEttan 2004). There have been reports of sexual and racial harassment, as well as threats and blackmail, by supervisors against female immigrant cleaners. A study by Åsa Hammar (2000) showed that the women's insufficient language skills, lack of knowledge about the society, and lack of union contacts partly undermined their credibility. A number of female immigrant cleaners, despite being seriously ill, do not dare to be sick-listed because this would risk negatively affecting the employer's view of them in future wage negotiations (Akhavan \& Bildt 2004).

The turbulent and tough business climate makes the situation more vulnerable for ordinary cleaners. Five unequal relations of power interact in aggravating their situation. 
Cleaners are in the lowest category of the working class, they are mostly low-educated, and they are either women or immigrants representing ethnicities and nationalities from outside of Europe. As a result, they pay a high price in the form of adverse working and employment conditions, part-time/un/employment, and a combination of part-time schedules involving working across a number of different locations. In addition, cleaners in Stockholm County earn significantly lower wages than cleaners in other regions. This is very likely due to an excessive number of cleaning firms in the region - approximately 1,200 firms - and also partially to a large share of part-time employees (Byggettan \& FastighetsEttan 2004). Individual wage setting, applying criteria such as training, work experience from the industry, rank, and commitment, may in the best of cases benefit some cleaners more than others.

\section{Theoretical model and statistical findings}

To study and analyze the cleaning industry in the county of Stockholm we have used both quantitative and qualitative methods. We have also tried to conceptualize the core dimensions affecting the situation of ordinary cleaners in a theoretical model that will help to guide us through our aims and questions. We start by presenting the model and then move on to present and discuss the statistics; the qualitative data will be used as illustration later on in the text.

Figure I: The theoretical model.

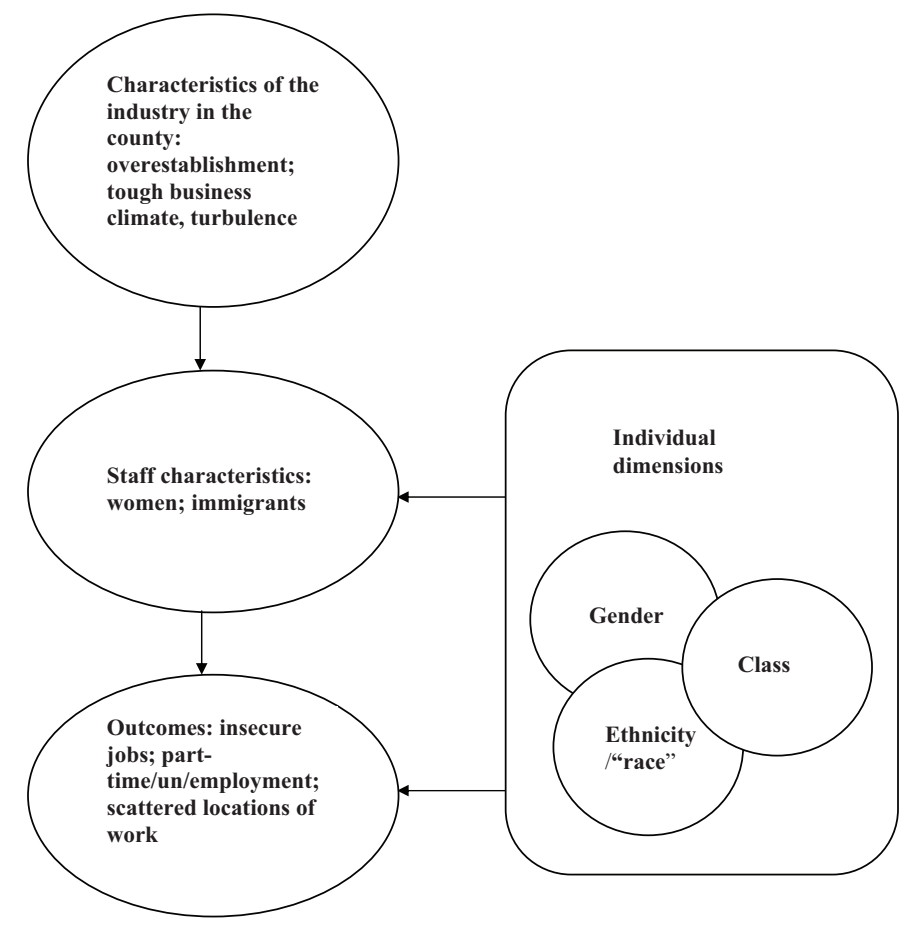


In the first circle, we claim that the cleaning industry in Stockholm county is an overestablished industry with too many firms. The business climate is tough and turbulent as these firms compete with each other by price-setting, rather than quality, as their principal competitive means. When a contract is approaching expiry, the competition gets harder, as the firms want to take over contracts from each other. The dominant majority of staff (Circle 2) are ordinary cleaners with no means of power to improve their situation in the regional industry. They are in general racialized women and men and native-born women. These staff characteristics give rise to the intersecting individual dimensions of gender, class, and ethnicity/race as indicated in the box on the right. These dimensions interact and intersect by keeping the cleaning workers (mentioned in Circle 2) in a powerless and subordinated position. The outcome of this interaction (Circle 3) becomes evident for ordinary cleaners in the form of insecure jobs, part-time/un/employment, and scattered working locations. It also helps to reproduce the general state of the regional industry.

Our quantitative data sources come from Statistics Sweden (the statistical database LOUISE, delivered in 2005), from statistics of joint-stock companies (D \& B 2004), and from internal statistics from the Swedish Municipal Workers' Union. A survey of statistics for 2004 and the names of the owners shows that a predominant majority of the approximately 500 joint-stock companies in Stockholm county had male owners, mainly of Nordic and in particular of Swedish origin. One-third of these companies had been in business for less than 10 years. A majority (383) of the firms had less than nine employees including the MD. A total of four large or very large companies, with 300 , 900, 3,000 and 6,800 employees, respectively, were found. The rest were small-sized firms with 10-199 employees (D \& B 2004).

The records of all these companies showed that their number of employees fluctuated over the years, which can be seen as a measure of the turbulence in the industry. Some firms suddenly reduced their staff by $70 \%$ within one fiscal year, while others increased by the same rate or more over the same period. A similar pattern was found with regard to economic turnover.

Nearly 16,000 people worked in the industry in Stockholm County in December 2002, a number comprising MDs as well as cleaners and white-collar workers. Twothirds of all employees in the industry were born outside Sweden (compared with $31 \%$ in the country as a whole - see SCB 2003). People born outside Europe (Latin America, Asia, Africa, and Oceania) constituted the largest group among the employees. A closer look at the statistics revealed that the most common nationalities, after Swedes, were persons born in Chile, Finland, Turkey, Greece, the former Yugoslavia, or Iraq. Of all employees, $53 \%$ were women and $47 \%$ were men. Compared with Sweden as a whole, where women make up $80 \%$ of all employees in the industry, we find almost equal shares of women and men in the regional cleaning industry of Stockholm. Data on country of birth included both people with and people without Swedish citizenship in all nationality groups. Many of those who were born in other countries, but also those who were born in Sweden to immigrant parents, still had non-Swedish citizenship, while a substantial group had become Swedish citizens (Table 1). ${ }^{2}$

While almost half of all male employees came from non-European countries, the share was $38 \%$ for women in this group. It is obvious that both men and women from outside Europe are overrepresented in the cleaning sector. At the same time, relatively 
Table I Employees and employers in the cleaning industry in Stockholm County according to native origin, gender, and percentage in each group, December 2002. (All tables were compiled by the authors.)

\begin{tabular}{lcccccc}
\hline Born in & \multicolumn{2}{c}{ Men } & \multicolumn{2}{c}{ Women } & \multicolumn{2}{c}{ Total } \\
\hline Sweden & 2,411 & $32 \%$ & 2,953 & $35 \%$ & 5,364 & $34 \%$ \\
\hline Rest of Europe & 1,462 & $19 \%$ & 2,206 & $26 \%$ & 3,668 & $23 \%$ \\
\hline Other & 3,679 & $49 \%$ & 3,203 & $38 \%$ & 6,882 & $43 \%$ \\
\hline Total & $7,552(47 \%)$ & 100 & $8,362(53 \%)$ & 99 & 15,914 & 100 \\
\hline
\end{tabular}

Source: Statistics Sweden (2005).

larger numbers and percentages of women than men were noted in the groups "born in Sweden" and "the rest of Europe."

Closer scrutiny of the statistics shows how the distribution of gender varies among different nationalities. In the groups born in Sweden, Finland, Turkey, the former Yugoslavia, Thailand, Poland, Bosnia, and Syria, there was a larger or sometimes considerably larger share of women than men, while the opposite was true for people born in Chile, Greece, Ethiopia, Peru, Iraq, Eritrea, Colombia, Somalia, Gambia, and Iran. The largest share of women in any nationality group were women born in Thailand (95\%), while women born in Somalia, with 23\%, displayed the lowest share in their nationality group compared with men. Aside from the fact that cleaning is considered a typically female occupation, one explanation for the differences between men and women in the nationality groups could be that some groups have, compared with others, a high or even higher representation of women than men, such as, for example, women from Thailand.

An interesting observation in Table 2 is that the proportion of people born in Sweden is highest in state-owned and municipality-owned companies, which means that the public sector is the primary employer in their case. Joint-stock companies and other types of firms stand out as the most important workplaces for persons from outside Europe. Joint-stock companies make up the bulk of cleaning firms in the county.

Table 2 Labor market sectors for employees and employers in the cleaning industry in Stockholm County according to birthplace, sector, December 2002.

\begin{tabular}{lcccccccccc}
\hline Variable & \multicolumn{10}{c}{ Sector } \\
\hline Born in & Municipality & Joint-stock company & Other type of firm & State owned & Total & $\%$ \\
\hline Sweden & 232 & $43 \%$ & 4,327 & $33 \%$ & 567 & $34 \%$ & 238 & $57 \%$ & 5,364 & $34 \%$ \\
\hline Rest of Europe & 155 & $29 \%$ & 3,067 & $23 \%$ & 414 & $25 \%$ & 32 & $8 \%$ & 3,668 & $23 \%$ \\
\hline Other & 154 & $28 \%$ & 5,914 & $44 \%$ & 666 & $40 \%$ & 148 & $35 \%$ & 6,882 & $43 \%$ \\
\hline Total & 541 & 100 & 13,308 & 100 & 1,647 & 99 & 418 & 100 & 15,914 & 100 \\
\hline$\%$ of industry & $3.4 \%$ & & $83.6 \%$ & & $10.3 \%$ & & $2.6 \%$ & & $100 \%$ & \\
\hline
\end{tabular}

Source: Statistics Sweden (2005). 
Table 3 Registered hourly-paid employees and part-time unemployed (aged 16-64 years) and a combination of the two registered at the Stockholm County employment agency, in Stockholm County's cleaning industry, distributed by gender, December 2002 (whole year data).

\begin{tabular}{lccccc}
\hline Variable & Total & \multicolumn{2}{c}{ Men } & \multicolumn{2}{c}{ Women } \\
\hline I. Per-hour employees & 733 & 352 & $48 \%$ & $38 \mid$ & $52 \%$ \\
\hline 2. Part-time unemployed & 697 & 314 & $45 \%$ & 383 & $55 \%$ \\
\hline 1 \& 2 & 97 & 38 & $39 \%$ & 59 & $61 \%$ \\
\hline
\end{tabular}

Source: Statistics Sweden (2005).

One of the important issues we set out to address was the type of employment contracts regulating working time for cleaners. This question is partly answered in Table 3.

Being registered at an employment agency implies that a person is actively looking for more regular work or a full-time job. Table 3 shows that employment by the hour and part-time unemployment are widespread among cleaners in the county. These contractual forms are equivalent to the share of women and men among the employees (53 and 47\%, respectively). The 97 persons in the third row (in the "Total" column) are included in both per-hour employees and part-time unemployed in the rows above. Consequently, the total number of people in the survey is 1,333, since the 97 appears twice. This corresponds to about $8 \%$ of all employees in the county's cleaning industry.

Table 4 shows that employment on an hourly basis or part-time unemployment is a problem that particularly applies to persons born outside of Europe. These types of insecure employment conditions apply to both genders in this group, but with a remarkable overrepresentation of men from outside Europe. Hypothetically, this could be due to the fact that non-European men meet difficulties in finding jobs at all and therefore have to accept irregular contracts and working hours to gain any access to the labor market. More detailed research would be needed to clarify this question. Women and men from the rest of Europe do best, while women born in Sweden do much less well than their male counterparts.

The cleaning sector does not require educational qualifications or particular credentials other than adequate training and preferably work experience in the industry. It is therefore interesting to see the educational backgrounds of persons in the sector.

Table 4 Per-hour employees and part-time unemployed in Stockholm County's cleaning industry by gender and birthplace, registered with the employment agency, December 2002 (whole year data).

\begin{tabular}{|c|c|c|c|c|c|c|c|c|c|c|c|c|}
\hline \multirow{3}{*}{$\begin{array}{l}\text { Variable } \\
\text { Per-hour } \\
\text { employees }\end{array}$} & \multicolumn{6}{|c|}{ Men born in } & \multicolumn{6}{|c|}{ Women born in } \\
\hline & \multicolumn{2}{|c|}{ Sweden } & \multicolumn{2}{|c|}{ Rest of Europe } & \multicolumn{2}{|c|}{ Other } & \multicolumn{2}{|c|}{ Sweden } & \multicolumn{2}{|c|}{ Rest of Europe } & \multicolumn{2}{|c|}{ Other } \\
\hline & 104 & $29 \%$ & 37 & $11 \%$ & 211 & $60 \%$ & 154 & $40 \%$ & 55 & $14 \%$ & 172 & $45 \%$ \\
\hline $\begin{array}{l}\text { Part-time } \\
\text { unemployed }\end{array}$ & 34 & $11 \%$ & 41 & $13 \%$ & 239 & $76 \%$ & 120 & $31 \%$ & 73 & $19 \%$ & 190 & $50 \%$ \\
\hline
\end{tabular}

Source: Statistics Sweden (2005). 
Table 5 Employees and employers in the cleaning industry in Stockholm County by educational level, gender, and birthplace, December 2002.

\begin{tabular}{|c|c|c|c|c|c|c|c|c|}
\hline \multirow[t]{2}{*}{ Born in } & \multicolumn{2}{|c|}{$\begin{array}{l}\text { Lower secondary } \\
\text { and less }\end{array}$} & \multicolumn{4}{|c|}{ Upper secondary University Education } & \multicolumn{2}{|c|}{ Total } \\
\hline & Men & Women & Men & Women & Men & Women & Men & Women \\
\hline Sweden & $\begin{array}{c}945 \\
(40 \%) \\
\end{array}$ & $\begin{array}{l}1,181 \\
(41 \%)\end{array}$ & $\begin{array}{l}1,116 \\
(48 \%)\end{array}$ & $\begin{array}{l}1,394 \\
(48 \%) \\
\end{array}$ & $\begin{array}{c}282 \\
(12 \%) \\
\end{array}$ & $\begin{array}{c}303 \\
(11 \%) \\
\end{array}$ & $2,343=100 \%$ & $2,878=100 \%$ \\
\hline $\begin{array}{l}\text { Remaining } \\
\text { Nordic countries }\end{array}$ & $\begin{array}{c}152 \\
(49 \%)\end{array}$ & $\begin{array}{c}499 \\
(54 \%)\end{array}$ & $\begin{array}{c}133 \\
(42 \%)\end{array}$ & $\begin{array}{c}343 \\
(37 \%)\end{array}$ & $\begin{array}{c}28 \\
(9 \%)\end{array}$ & $\begin{array}{c}74 \\
(8 \%)\end{array}$ & $313=100 \%$ & $916=100 \%$ \\
\hline $\begin{array}{l}\text { Rest of Europe } \\
\text { and the former } \\
\text { Soviet Union }\end{array}$ & $\begin{array}{l}359 \\
(31 \%)\end{array}$ & $\begin{array}{l}423 \\
(32 \%)\end{array}$ & $\begin{array}{c}460 \\
(40 \%)\end{array}$ & $\begin{array}{c}487 \\
(37 \%)\end{array}$ & $\begin{array}{c}331 \\
(29 \%)\end{array}$ & $\begin{array}{l}420 \\
(31 \%)\end{array}$ & $1,150=100 \%$ & $1,330=100 \%$ \\
\hline Africa & $\begin{array}{l}413 \\
(32 \%)\end{array}$ & $\begin{array}{c}344 \\
(48 \%)\end{array}$ & $\begin{array}{c}569 \\
(44 \%)\end{array}$ & $\begin{array}{c}209 \\
(29 \%)\end{array}$ & $\begin{array}{l}306 \\
(24 \%)\end{array}$ & $\begin{array}{l}166 \\
(23 \%)\end{array}$ & $1,288=100 \%$ & $719=100 \%$ \\
\hline $\begin{array}{l}\text { Asia incl. } \\
\text { Turkey }\end{array}$ & $\begin{array}{l}460 \\
(40 \% \\
\end{array}$ & $\begin{array}{c}883 \\
(59 \%) \\
\end{array}$ & $\begin{array}{c}372 \\
(33 \%) \\
\end{array}$ & $\begin{array}{c}311 \\
(21 \%) \\
\end{array}$ & $\begin{array}{c}304 \\
(27 \%) \\
\end{array}$ & $\begin{array}{c}303 \\
(20 \%) \\
\end{array}$ & $1,136=100 \%$ & $1,497=100 \%$ \\
\hline $\begin{array}{l}\text { North \& Latin } \\
\text { America }\end{array}$ & $\begin{array}{c}402 \\
(32 \%)\end{array}$ & $\begin{array}{c}333 \\
(37 \%)\end{array}$ & $\begin{array}{c}504 \\
(40 \%)\end{array}$ & $\begin{array}{c}333 \\
(37 \%) \\
\end{array}$ & $\begin{array}{l}356 \\
(28 \%) \\
\end{array}$ & $\begin{array}{c}244 \\
(26 \%) \\
\end{array}$ & $1,262=100 \%$ & $910=100 \%$ \\
\hline $\begin{array}{l}\text { Other and } \\
\text { Unknown }\end{array}$ & $\begin{array}{c}10 \\
(27 \%) \\
\end{array}$ & $\begin{array}{c}9 \\
(32 \%) \\
\end{array}$ & $\begin{array}{c}12 \\
(32 \%) \\
\end{array}$ & $\begin{array}{c}6 \\
(21 \%) \\
\end{array}$ & $\begin{array}{c}15 \\
(41 \%) \\
\end{array}$ & $\begin{array}{c}13 \\
(46 \%)\end{array}$ & $37=100 \%$ & $28=100 \%$ \\
\hline \multirow{2}{*}{$\begin{array}{l}\text { Total and } \\
\text { Percentage }\end{array}$} & 2,741 & 3,672 & 3,166 & 3,083 & 1,622 & 1,523 & 7,529 & 8,278 \\
\hline & $36 \%$ & $44 \%$ & $42 \%$ & $37 \%$ & $22 \%$ & $18 \%$ & $48 \%$ & $52 \%$ \\
\hline
\end{tabular}

Source: Statistics Sweden (2005).

Table 5 shows that $41 \%$ have lower secondary education or less, while as many as around $20 \%$ of all employees, both women and men, have a university education and $39 \%$ have an upper secondary education. People born in and outside of Europe have a significantly higher share of university education than people born in Sweden and the other Nordic countries. This indicates that ethnicity and class intersect in a social movement downward, from previously having been part of the middle or upper classes to ending up in the working class, in Sweden. This is particularly true for men, who in general have higher educational levels than women. A closer look at the statistics shows that people born in Peru (47\% with university degree) had the highest education, followed by those born in Colombia, Poland, Iraq, and Greece, whose education not only corresponded to the average in Sweden but also in some cases surpassed it. ${ }^{3}$ On the other hand, there is a significantly larger share of people with lower secondary education or less among people born in Turkey, Thailand, Syria, Finland, and Eritrea. One conclusion we draw from our data is that the cleaning industry offers job opportunities to both extremes of the educational scale. It is true that there is an overweight of lower educational levels; yet, one-fifth of those working in the industry are educationally overqualified, something that is particularly true for some foreign-born nationals.

To sum up the quantitative data, we can see a correlation between our theoretical model and the statistical results in this section. The majority of employees in the county's 
cleaning industry are Swedish women and male and female immigrants, not least from outside of Europe, something that indicates an intersection between gender and ethnicity/race. A large amount of all cleaners, especially those of non-European origin, are employed in joint-stock companies. A predominant number of these companies have, according to D \& B (2004), owners of Nordic origin. Part-time unemployment and perhour employment is more common in joint-stock companies than in firms with other legal forms and both these types of contracts are more common among women than men. On a detailed level, this holds true even for well-educated men and women. Men and women from non-European countries, as well as those from other European countries, have university-level education more often than Swedish and other Nordic nationals do, but they nevertheless end up as ordinary cleaners in Stockholm County. This indicates the workings of a subordinating intersection of gender, class, and ethnicity/race.

\section{The interview investigation}

To supplement our quantitative data and to get access to personal views and experiences, we conducted face-to-face field investigations with seven MDs (one female, six male), four deputy MDs, and 10 cleaners (see Table 6). The interviews, which lasted on average 45 minutes, were carried out in 2004 and 2005. In all, two of the MDs had a non-European background, while the rest were Nordic or Swedish. Despite our endeavor to interview part-time working cleaners, nine of the cleaners introduced to us by the MDs worked full-time. Although this was a drawback, we decided to interview them, not least because they had good knowledge of the industry that would give us material with which to illustrate some typical aspects. Some of the respondents had previously worked part-time and could be instrumental in our investigation. ${ }^{4}$

Table 6 Cleaners interviewed in 2005.

\begin{tabular}{llll}
\hline Men, Age & Place of birth & Highest education & $\begin{array}{l}\text { Working years as } \\
\text { cleaner in Sweden }\end{array}$ \\
\hline Morris, 34 & Ghana & Upper secondary school & I। \\
\hline Julio, 43 & Chile & University degree in economics & 4 \\
\hline Richard, 35 & Sri Lanka & University degree in electronics & Several years \\
\hline Hassan, 45 & Morocco & Elementary school 4 years & I5 \\
\hline Marlong, 35 & Nicaragua & Unfinished university education & Less than I \\
\hline Women, Age & & & 2.5 \\
\hline Monika, 39 & Estonia & Trade school & 30 \\
\hline Sofia, 65 & Sweden & Middle school & I \\
\hline Camilla, 29 & Sweden & Upper secondary school & 2 \\
\hline Margareta, 48 & Sweden & Compulsory school & 2 \\
\hline Gina, 38 & Thailand & University degree in management & \\
\hline
\end{tabular}


All the interviewed cleaners had previous experience of the work, in their native countries, elsewhere in Sweden, or in other countries. Most of them had attended various courses in addition to their ordinary education. Those with a university degree had gained their degrees in their native countries.

Part-time employment, not least the involuntary type, is a sign of the adverse working conditions in the regional cleaning industry and was one of the starting points for the article. We have to admit, however, that it is sometimes difficult to define the boundary between voluntary part-time and involuntary part-time/un/employment. The problem involves women more often than men, and as statistics show, women outnumber men in the sector. Since they are more often responsible for domestic work, this prevents them physically and psychologically from working full-time. Due to their double burden, they may find it more difficult to cope with different workplaces and employers. Men do not face the same problems. As a result, they can be preferred by the employers, which means that they have better opportunities to get full-time jobs than women do. Gender could, in line with our theoretical model, work as a disadvantageous factor for female cleaners.

Interviews with the two trade union project leaders, MDs, and cleaners indicate that various push and pull factors play a part in this context. Quotes from the interviews serve as illustrations of some typical views and aspects. One major factor seems to be the clients, who decide right from the start that a job will have to be performed on a part-time basis:

The market rules and we cannot influence it. A client who books a service decides if it should be full-time or part-time. It is the client's need that rules. He says he needs four hours of cleaning and we cannot do more (MD in firm F).

As our model indirectly indicates, the client's demands on the type of service directly affect the number of working hours. The company owners give their employees a parttime schedule at the client's workplace.

But there also seems to be a conception among MDs that part-time work among cleaners is something that is voluntary and is only an extra job for many people to earn some money. Here is a typical quotation in this regard:

There are people who work part-time for different reasons like studies. There are even those who really want to work less than eight hours per day (MD in firm B).

Even some of the interviewed cleaners themselves argued that part-time work among cleaners was a voluntary matter:

Those who work $60 \%$ are in most cases people with small children, but many others do it to have more leisure time. They have saved money, so they have enough to spend on leisure activities (Margareta, cleaner).

We once again see that gender might play a role, since it is mostly women who, due to domestic work or care of children, work part-time. One of the MDs, however, makes no secret of the fact that there is a certain advantage in having part-time cleaners: 
There is an attitude in the industry that when a part-time worker gets sick, it is easier to substitute her than a full-time worker (MD in firm B).

In accordance with our model, this quote could be interpreted as an expression of superiority over those without power, the cleaners. It could be considered that owners of firms deliberately act to maintain a permanent part-time crew and as a result contribute to more insecurity.

Part-time cleaners can apply for a full-time schedule with their current employers, but they cannot be certain of getting it. Many employers hire cleaners first for probationary employment and may, in the best of cases, grant them full-time later on. There always seems to be some kind of uncertainty, as is apparent from the following quotation:

You get full-time - if it is possible (Richard, cleaner).

The factors making access to full-time employment possible remain in this case unexplained. But as the two quotes above indicate, it is not only the client's role that accounts for part-time contracts, nor is the statement that part-time work among cleaners is voluntary an absolute truth. Some of the cleaners who were now working full-time had actually had a part-time schedule to start with.

There are certain criteria that the cleaners must fulfill if they want more hours from the employers. The length of work experience and, of course, getting the job done are the most common criteria in a normal ranking system, as expressed in the following quotation:

It is also based on working experience among the staff and the number of years in the firm.

Those with longer experience have priority (Hassan, cleaner).

Yet this cannot be the only explanation, because there are people who are involuntarily working part-time even after several years in the industry. Julio, with a university degree in economics, is the only part-timer in the study and still works no more than 30 hours per week after four years in the industry. His answer to the question why he works parttime was

I don't know. It's just a contract I have got. But I would prefer to work full-time. Sometimes I have one or two substitute hours, but normally I have six hours a day (Julio, cleaner).

Is Julio's ethnic background contributing to his class journey downward, and does it also constitute a disadvantage to getting a full-time schedule?

Experience of the job and the industry does not automatically guarantee a full-time schedule. Some of the cleaners have had permanent full-time schedules from the beginning, in spite of the fact that they had no industry experience at all. Two of them got full-time jobs shortly after their arrival in Sweden. One possible explanation could be favorable contacts, representing a form of social capital (see, e.g., Behtoui 2006): One was married to a Chilean-Swedish woman working at the municipality, the other to a Swedish man. It is thus possible to get a full-time job even without a long history of industry experience and poor Swedish language skills. Obviously, employers do not 
always treat their cleaners equally, and the ethnic dimension might interfere to their disadvantage. One can suspect, when comparing these two persons' situation with that of Julio, who lacks influential social capital, that there is an element of discrimination. He has not, despite several years of experience in the industry, succeeded in getting a full-time job.

Lack of proficiency in the Swedish language can be used by employers to deny workers full-time hours. This was the case with one MD who himself had an immigrant background. There is clearly a risk for discrimination, since the judgment of language skills depends entirely on the employer and what he or she considers satisfactory, while the jobseeker has no power to question the judgment. This risks excluding cleaners with long experience in the firm from opportunities to become full-time employed if they are considered not to speak Swedish as well as the employer expects:

If someone can speak a little, they may get a part-time schedule. But to get increased hours or full-time they must speak well and communicate with the clients and understand what they say (MD of firm G).

This is quite different from the two cases above who, despite having been in Sweden for only a short time and having insufficient language skills, were given a full-time schedule right from the beginning thanks to their strong social capital. This example shows that probationary part-time employment and ranking according to experience and number of years on the job is by no means always conclusive. There seems to be no simple or clearcut explanation of why one person gets a full-time job and another person does not.

Just as well as employers may use irregular or undocumented labor, part-time work can sometimes be an attempt by cleaners to cheat the welfare system:

There are people working $60 \%$, who do not wear themselves out. They know that they can get the rest as unemployment insurance benefits. People must try hard to find a supplementary job or apply for increased hours or full-time with their current employers (Marlong, cleaner).

According to one of the unions that organizes cleaning workers (FastighetsEttan 2005), it is not only cleaners but also employers who are cheating the system through irregular labor. Some cleaners combine two or three part-time jobs to reach $100 \%$ employment (Interview with FastighetsEttan's representative September 21, 2004), while others avoid doing so due to practical problems such as, for example, women's responsibilities for home and family. In many cases, the jobs are situated in separate municipalities. Sometimes, the cleaner must change between three part-time job locations during the same day. If the cleaner does not get compensation for lost traveling time, there is a risk that she or he will give up full-time work in combined jobs. As mentioned before, having to combine jobs in different places can be a major problem, especially for women. This problem was confirmed both by a union representative (Interviews with FastighetsEttan's representative April 13, 2004, \& May 2, 2005) and by one of the female cleaners:

If there are several workplaces, then they must be close to each other. Distance makes people unwilling to work full-time, if they must travel far. People easily get tired (Sofia, cleaner). 
Being allotted scattered cleaning locations is obviously an extra strain in the cleaning sector, on top of the insecure, part-time, and low-paid conditions.

\section{Conclusions and Discussion}

The statistics we have presented show that the market for cleaning in the Stockholm region is mostly controlled by male owners of Nordic and, not least, Swedish origin. The extremely variable results seen in the firms' annual books are a sign of turbulence in this market and indicate that the number of clients and contracts varies from year to year. This also results in tough competition between these firms.

As has become evident, cleaning is a gender- and ethnically segregated low-income and low-status occupation, something that is as true for Sweden as a whole as it is for the county of Stockholm. The staff body in the regional cleaning industry is dominated by ordinary cleaners, the majority of whom come from other - predominantly nonEuropean - countries. Most of them have low levels of education. At the same time, however, we found that cleaners from a number of non-Nordic countries had higher educational levels than Swedish citizens and those from the Nordic countries and yet were trapped in this low-status job. Part-time/un/employment is principally a problem for female cleaners, whether Swedish or immigrant, as well as for male immigrant cleaners from non-European countries. As cleaners, they have little or no access to power that would help them to change their situation. In our qualitative interviews, we found three overarching categories of explanations for part-time employment and part-time/ un/employment - that is, involuntary part-time work - among cleaners. We define the three as push categories that force the cleaners into part-time employment and part-time unemployment. These categories are as follows:

\section{The role of clients and firms}

Clients, the purchasers of cleaning services, and firms rule the market. Firms compete to get new contracts or to renew or prolong existing contracts with clients, trying to stay in business. This is an expression of what we refer to as "turbulence" in our theoretical model. The contracts are based on cleaning projects and surfaces; therefore, the first group affected by the contract conditions is ordinary cleaners, not so much other employees. In addition, clients often want part-time services only. The outcome is doubleedged - on the one hand, it secures jobs for the cleaners; if the owners of the firms do not get new contracts, the cleaners risk being pushed out and made redundant. On the other hand, this implies that these two actors are using the cleaners and their labor power and are reaping the benefits of their work by paying low wages. Cleaners have nothing to set against these two powerful players.

\section{Discriminatory practices}

Most owners of firms start by offering part-time positions, but seem to be discriminating against or disfavoring some cleaners while favoring others. Relatively recent immigrants 
with powerful connections or contacts, in the form of social capital, can easily be promoted to full-time employment, while others with long experience and good knowledge of the industry continue to work part-time. Employers also tend to discriminate against cleaners who are not considered to speak Swedish well enough. The ethnic dimension intersects with their subordinated class position. This appears to be true not only for women of immigrant origin but also for men from outside Europe.

\section{Demanding schedules}

Cleaning jobs are more often than not scattered in different locations. It is therefore necessary to combine jobs in different places to achieve $100 \%$ employment. We notice again that it is especially difficult for women to travel between different places and municipalities, because they are more likely to be responsible for taking care of the home and children. If the cleaner does not receive compensation for time lost in traveling, it is also likely that she or he will give up working full-time in combined jobs.

Naturally we also came across some cases of voluntary part-time work, something that could be defined as a pull category. There are cleaners who themselves choose to work part-time permanently, while others choose to work part-time temporarily due to other tasks - studying, for example. As mentioned by several respondents, there are also part-time cleaners who, in agreement with their employers, cheat the tax authorities.

The aim of this paper has been to explain and analyze the problematic situation that the cleaning industry and cleaners in the region of Stockholm find themselves in. Although similar drawbacks are found across the entire country, the cleaning industry is more problem-ridden in Stockholm County than it is in other Swedish regions. It is a business branch that is exposed to great pressures due to tough competition in the sector and economic ups and downs. An important aspect of the problems in the regional cleaning industry is the excessive number of firms and harsh competition between them. The industry suffers from over establishment, a tough business climate, and turbulence as a result of the new NPM reform and market-driven rules. Many less honest firms have been established here. Bankruptcy and replacement of owners and staff, as well as short life duration of firms, are common, especially in a recession. Under such circumstances, and not least during quotation procedures, there may be a price war rather than competition on grounds of quality. For each cleaning assignment, the owner of the firm decides what has to be done and what the employees will have to do. The burden placed on the cleaning firms therefore spills over to ordinary cleaners in the form of part-time employment, difficult working conditions, and low wages. It is the cleaners who in the end have to cope with the constant stress and insecurity related to the risk of being made redundant.

While one-third of all cleaners in Sweden are immigrants, the corresponding amount for the county of Stockholm is two-thirds. Many do not have access to a social network, lack good language skills, and may have limited work experience, low educational levels, and limited knowledge of Swedish laws and regulations. They have no assets of power that would help them to improve their conditions of employment and defend their rights when it comes to setting of wage rates and procurement procedures. There are, on the other hand, a number who have good language skills, good knowledge of laws and regu- 
lations, and a university degree and yet find themselves in almost the same powerless situation. Due to their ethnic background, they find themselves in a downward spiral in relation to their socioeconomic class background.

We have tried to show how the socially organizing categories of gender, class educational level and position in work life - and ethnicity/"race" intersect to create a vulnerable situation for the cleaners - a situation that forces them to accept involuntary part-time work (that is, part-time unemployment), scattered locations of work, and insecure contracts. The industry is clearly genderized and racialized, since the cleaners are to a large extent women and men from various ethnicities/races, not least from nonEuropean countries (cf. also Nelander \& Bendetcedotter 2001; Nyberg 2003). Based on our data and our theoretical model, and with support from earlier research with regard to the Swedish labor market (de los Reyes 2001; Stolke 1993; Thomsson 2001), we argue that these intersections are evident in the cleaning industry in Stockholm county, leading to adverse working and employment conditions and helping to sustain the problematic state of the industry.

We are aware that more research is needed to answer questions related to irregular employment contracts, such as work by the hour and part-time unemployment, to clarify the use of undocumented immigrant workers and to get a clearer picture of why certain groups or categories of people are affected more negatively than others. What we can argue, with some certainty, is that gender, class, and ethnicity/"race" are intersecting social dimensions that are working to the detriment of ordinary cleaners.

\section{Acknowledgment}

We wish to thank Associate Professor Emerita Wuokko Knocke for her valuable help in re-editing and improving this paper.

\section{References}

Abbasian, S. (2006) Deltidsarbete och deltidsarbetslöshet bland städare i Stockholms länEn studie av integration och jämställdhet (Part-time work and part-time unemployment among cleaners in Stockholm County- A study of integration and equality). Working paper 6 från HELA-projektet, Arbetslivsinstitutet: Stockholm.

Akhavan, S., and Bildt, C. (2004) Arbetsvillkor, hälsa och sjukfrånvaro bland invandrade kvinnor (Working Conditions, Health and Sick-Leave among Immigrant Women). Arbetslivsrapport nr. 2004: 21. Stockholm: Arbetslivsinstitutet.

Ålund, A. (1985) Skyddsmurar - Etnicitet och klass i invandrarsammanhang (Protect Walls Ethnicity and Class in Immigrant Context). Liber: Stockholm.

Ålund, A. (2002) 'Kultur som möjligheternas basar (Culture as a Bazaar of the Possibilities)'. Invandrare and Minoriteter 1, pp. 19-24.

Aurell, M. (2001) Arbete och identitet: om hur städare blir städare (Work and Identity: On How Cleaners Become Cleaners). Linköpings Universitet, Tema Teknik och social förändring.

Behtoui, A. (2006) Unequal Opportunities. The Impact of Social Capital and Recruitment Methods on Immigrants and their Children in the Swedish Labour Market. PhD Thesis, Linköping University. 
Burr, H., Bjorner, J. B., Kristensen, T. S., Tüchsen, F., and Bach, E. (2003) 'Trends in the Danish Work Environment in 1990-2000 and their Associations with Labor-Force Changes'. Scandinavian Journal of Work, Environment and Health 29(4): 270-79.

Byggettan's application to HELA-projektet January 14, 2004, Record no. HELA 20023/ 30794.

D \& B (2004) Branschfakta - städföretag 2004:5 (Industry fact - Cleaning Firms number 2004:5). Stockholm: Dun and Bradstreet Ekonomiförlaget AB.

Dahl, U. (2005) Fran hatbrott och homofobi till heteronormativetet och intersektionalitet En kunskapsinventering och situering av forskning (From Hate Crime and Homophobia to Heteronormativity - A Knowledge Inventory and Positioning of the Research). Stockholm: Forum för levande historia. Collected December 2010 from: http://www.levandehistoria.se/files/hbt_rapport.pdf

de los Reyes, P. (2001) Màngfald och differentiering. Diskurs, olikhet och normbildning inom svensk forskning och sambällsdebatt (Diversity and Differentiation. Discourse, Disparity and Norm Creating within Swedish Research and Public Debate). Solna: Arbetslivsinstitutet.

de los Reyes, P., and Mulinari, D. (2005) Intersektionalitet - Kritiska reflektioner över (o) jämlikhetens landskap (Intersectionality - Critical Reflections on the Landscape of (In) equality). Liber: Malmö.

de los Reyes, P., Molina, I., and Mulinari, D. (eds.) (2002) Maktens (o) lika förklädnader. Kön, klass and etnicitet $i$ det postkoloniala Sverige (D)ifferent Disguises of Power: Gender, Class and Ethnicity in the Post Colonial Sweden). Stockholm: Bokförlaget Atlas.

E-mail interview with representative from the union FastighetsEttan, June 20, 2005.

Ekelöf, M. (1970) Rapport från en skurhink (Report from a Mop Bucket). Stockholm: Rabén \& Sjögren.

European Agency for Safety and Health at Work (2009) Literature Review - The European Safety and Health of Cleaning Workers. Report TE-80-10-197-EN-N.

FastighetsEttan's application to HELA-projektet January 15, 2004, Record no. HELA 2004/184.

FastighetsEttan (2005) Intern rapport om svartarbete, skattefusk och bluffdeltid i oseriösa städföretag (Inhouse Report on Unregulated Labor, Tax Evasion and Bluff Part Time in Non-Serious Cleaning Firms). Framställd av Gesa Markusson. FastighetsEttan i Stockholm.

Fastighet's folket (2/2005) Städkontrakt borde handla mer än pengar (Cleaning Contract Should Deal with More than Money).

Fredholm, K (2003) Svenskt slavarbete (Swedish Slave Labor), Alla 2003-10-05. Stockholm: LO. Collected 2004-07-12 from http://alla.lo.se/news.asp?articleID=912.

Gonäs, L., Johansson, S., and Svärd, I. (1997) Lokala utfall av den offentliga sektorns omvandling (Local Outcomes of the Public Sector's Transition). In: E. Sundin (ed.), Om makt och kön, pp. 105-148. Statens offentliga utredningar, Stockholm: Fritzes.

Hammar, A. (2000) Som om vi inte finns - om rasism och sexism $i$ städbranschen (Just as if We are Not Existing - on Racism and Sexism in the Cleaning Industry). Stockholm: Federativ.

hooks, b. (1981) Ain't I a Woman: Black Women and Feminism. Boston: South End Press.

hooks, b. (1984) From Margin to Center. Boston: South End Press.

hooks, b. (1988) Talking Back: Thinking Feminist, Thinking Black. Boston: South End Press.

Interview with the representative of the union FastighetsEttan, April 13, 2004, September 21, 2004 and May 2, 2005.

Interviews with seven MDs and four deputy MDs in cleaning firms in Stockholm County June 9 and 21, 2004, October 18 and 20, 2004, April 20 and 27, 2005. 
Interviews with 10 cleaners in Stockholm February 22 and 24, 2005 and May 13, 2005.

Jonsson, A. and Wallette, M. (2001) 'Är utländska medborgare segmenterade mot atypiska arbeten? (Are Foreign Citizens Segmented Towards Atypical Jobs?)'. Arbetsmarknad and Arbetsliv, Årgång 7 Nr. 3, pp. 153-168.

Knocke, W. (1986) Invandrade kvinnor i lönearbete och fack (Immigrant Women in Salaried Employment and Union). Forskningsrapport 53, Stockholm: Arbetslivscentrum.

Knudsen, S. V. (2006) 'Intersectionality - A Theoretical Inspiration in the Analysis of Minority Cultures and Identities in Textbook'. In: É. Bruillard, B. Aamotsbakken, S. V. Knudsen, and M. Horsley (eds.), Caught in the Web or Lost in the Textbook. Collected December 2010 at http://www.caen.iufm.fr/colloque_iartem/pdf/part_I.pdf

Lundahl, M. (2006) 'Från genus till sexuell och etnisk skillnad (From Gender to Sexual and Ethnic Difference)'. In: L. Lennerhe (ed.), Från Sapfo till cyborg - idéer om kön och sexualitet $i$ historien, pp. 201-233. Gidlunds.

Marklund, A. M. and Ekenvall, L. (1998) 'Vi städar bra fast vi har sjal - Uppfölining av en grupp uppsagda städerskor (We clean up well though we have shawl-Follow up of a group noticed female cleaners)'. Stockholm: Karolinska Institutet, Yrkesmedicin.

Meetings with the two project leaders from the unions FastighetsEttan and Byggettan, April 13, 2004 and September 21, 2004.

Mohanty, C. T. (1984) 'Under Western Eyes: Feminist Scholarship and Colonial Discourses'. boundary Vol. 12(3), pp. 333-358.

Mohanty, C. T. (1991) 'Cartographies of Struggle: Third World Women and the Politics of Feminism'. In C. T. Mohanty, A. Russo and I. Torres (eds), Third World Women and the Politics of Feminism. Bloomington: Indiana University Press.

Mulinari, P. (2007) Maktens fantasier och servicearbetets praktik: arbetsvillkor inom hotelloch restaurangbranschen i Malmö (The Fantasies of the Power and Service Work Practice: Working Conditions within Hotel and Restaurant Sector in Malmö). PhD Thesis, Linköping University, theme Gender studies.

Nelander, S. and Bendetcedotter, M. (2001) Anställningsformer och arbetstider 2001 ett faktamaterial om välfärdsutvecklingen (Types of Employment and Working Time 2001 - a Fact Material on the Development of the Welfare). Nr. 52, Stockholm: LO, Löne- och välfärdsenheten.

Nyberg, A. (2003) Deltidsarbete och deltidsarbetslöshet - en uppföljning av DELTA-utredningen (SOU 1999:27 (Part-Time Working and Part-Time Unemployment - A Follow Up of the DELTA Investigation SOU 1999:27). Working Paper 2003:1 från HELAprojektet. Stockholm: Arbetslivsinstitutet.

Palmgren, J. (1995) Bara en städare?(Only a Cleaner?). D-uppsats i sociologi från Linköpings universitet.

Pettersson, H. (2005) A-kassa på deltid - ett ständigt problem inom arbetslöshetsförsäkringen (Unemployment Benefit on Part Time - A Continuous Problem within Unemployment Insurance). Working Paper 2005:3 från HELA-projektet. Stockholm: Arbetslivsinstitutet.

Prevent (2003) Farligaste jobben kartlagda (The Most Dangerous Jobs are Mapped (200309-15). Collected June 18, 2012 at http://www.prevent.se/sv/Arbetsliv/Artikel/2003/AFArapport-om-allvarliga-arbetsskador-Farligaste-jobben-kartlagda/

Prevent (2012) Hudbesvär bland städare $p g$ a våtarbete (Skin disorder among cleaners because of wet work). Collected June 18, 2012 at http://www.prevent.se/sv/KemiGuiden/ Statistik/Kemiska-arbetsskador-som-minskar/Hudbesvar-vatarbete/

Statistics Sweden (SCB) (2002) Befolkningens utbildning 2002 (SCB, Education 2002).

SCB (2003) Städare, vanligt yrke bland utrikes födda (Cleaner, Ordinary Job among Foreign Born). Pres sinformation från SCB 2003-10-15. Collected February 11, 2005, at www. scb.se 
SCB (2005) Statistics on the cleaning industry in Stockholm County, based on Database LOUISE.

SCB (2005a) 20 vanligaste yrkesgrupperna för kvinnor (20 Most Ordinary Occupations for Women). Collected February 7, 2005, at www.scb.se

SCB (2005b) 30 största yrkesgrupperna (30 Largest Occupational Groups). Collected February 7,2005 , at www.scb.se

SCB (2005c) Yrkeskoder enligt SSYK (Occupational Codes According to SSYK). Collected March 18, 2005, at www.scb.se

Stark, A., and Regnér, Å. (2001) 'I vems händer? Om arbete, genus, àldrande och omsorg $i$ tre EU-länder (In Whose Hands? On Work, Gender, Aging and Care in Three EU Countries)'. Tema Genus, Rapport nr. 1: 2001: Linköpings universitet.

Stolke, V. (1993) 'Is sex to gender as race is to ethnicity?' In: T. Del Valle (ed.), Gendered Anthropology, pp. 17-37. London: Routledge.

Sundin, E. (2005) Arbetsgivaren som förlorade heltid (The Employer who Lost Full Time). Arbetslivsrapport nr. 2005: 20, Stockholm: Arbetslivsinstitutet.

Sundin, E. and Rapp, G. (2006) 'Städerskorna som försvann: individen i den offentliga sektorn (The female cleaners who disappeared: the individual in the public sector)'. Arbetsliv i omvandling 2006: 2. Stockholm: Arbetslivsinstitutet.

Swedish Municipal Workers' Union (Kommunal, 2005) 'Internal Statistics for March and April 2005'.

Telephone interviews with representatives from the unions FastighetsEttan, Byggettan, Kommunal, June 15, 2005.

Thomsson, H. (2001) 'Vi vita, västerländska heterosexuella medelklasskvinnor (We White Western Heterosexual Middle Class Women)'. NIKK magasin no. 1/2001.

Torvatn SINTEF, H. (2011) 'Cleaning in Norway - Between Professionalism and Junk Enterprises’. Walqing social partnership series 2011.5, Trondheim.

Ulfsdotter Eriksson, Y. (2006) Yrke, Status \& Genus-En sociologisk studie om yrken på en segregerad arbetsmarknad (Job, Status and Gender - A Sociological Study of Jobs in a Segregated Labor Market). Göteborg Studies of Sociology No 29, Department of Sociology, Göteborg University.

\section{End notes}

${ }^{1}$ Space does not allow us to elaborate the situation in other Nordic countries. But in Denmark and Norway, and to some degree in Finland, similar trends/problems concerning characteristics of cleaners, cleaning jobs, their low status, and bad working conditions in the cleaning industry in general have been reported (see, e.g., Burr et al. 2003; European Agency for Safety and Health at Work 2009; Torvatn SINTEF 2011).

${ }^{2}$ For confidentiality reasons we have chosen not to present detailed data on individual nationality groups except for people born in Sweden. Data on region of birth were distributed among two groups: those who had become Swedish citizens and those who had not. A survey of the underlying statistics showed that a majority of the employees in the industry were Swedish citizens.

${ }^{3} 32 \%$ of all men and women born in Sweden had an academic education in 2002. Women were more educated. At the same time, $48 \%$ of all men and women born in Sweden had an upper secondary education (SCB, Befolkningens utbildning 2002).

${ }^{4} \mathrm{~A}$ disadvantage in this study is the absence of clients who buy cleaning services from the firms. 